\title{
EFEKTIFITAS HEPA FILTER DENGAN CHARCOAL DALAM PENYARINGAN ORGANOFOSFAT DI KABIN PESAWAT
}

\author{
Ferdi Afian", Ardhito Budhijuwono**, Amilya Agustina ${ }^{* * *}$, Dasti Anditiarina**** \\ *Program Studi Kedokteran Penerbangan, Departemen Ilmu Kedokteran Komunitas, \\ Fakultas Kedokteran Universitas Indonesia \\ **Fakultas Kedokteran Universitas Islam Al-Azhar \\ Email : drferdiaf@gmail.com
}

\begin{abstract}
ABSTRAK
Kontaminan yang dihasilkan di dalam kabin merupakan hal yang paling penting untuk diperhatikan dan harus dikontrol dimana yang termasuk di dalamnya adalah bau badan manusia, aerosol mikroba, Volatile Organic Compound (VOC), gas karbon dioksida, dan gas karbon monoksida. Teknologi penyaring udara dalam penerbangan menggunakan sistem High Efficiency Particulate Air (HEPA) dan Karbon Aktif. Teknologi ini dalam penggunaannya telah dimanfaatkan secara luas dalam dunia kerja dan penerbangan untuk menjaga kualitas udara dalam ruangan. Dengan prinsip mekanisme kerjanya filter ini memiliki kelebihan dalam hal menyaring partikel yang berukuran sangat kecil. Karbon aktif dalam bentuk charcoal telah diketahui secara luas dalam efeknya untuk menyaring sejumlah besar zat toksik seperti VOC dan bau tidak sedap dalam gedung dan kabin.
\end{abstract}

Kata Kunci: Penerbangan, HEPA, Karbon Aktif, Kabin.

\section{PENDAHULUAN}

Dewasa ini perkembangan teknologi pesawat terbang dan penggunaannya yang telah berdampak besar memiliki berbagai hal penting untuk diperhatikan, salah satunya adalah kualitas udara di dalam kabin pesawat. Kualitas udara kabin dipengaruhi oleh bleed air, sumber dari luar kabin, dan emisi dari sumber gas dalam kabin itu sendiri. penumpang dan aircrew dapat mengalami gangguan dari kualitas udara yang buruk dikarenakan sistem ventilasi yang tidak efektif dalam kabin pesawat. (Solbu K, 2011)

Potensi berbahaya dari zat berbahaya dalam kabin sudah dilakukan pada beberapa penelitian. Penelitian tersebut membawa kita kepada teknologi

Jurnal Kedokteran

Vol. 06 No. 01 Desember 2020 yang dapat meminimalisir dampak dari polusi udara dalam kabin pesawat. Sistem filtrasi dan pembersihan udara telah digunakan dalam pesawat untuk mengurangi efek dari polutan di dalam kabin dengan cara menghilangkan kontaminan udara dari suplai udara kabin. (Magoha, 2012)

Kontaminan yang dihasilkan di dalam kabin merupakan hal yang paling penting untuk diperhatikan dan harus dikontrol dimana yang termasuk di dalamnya adalah bau badan manusia, aerosol mikroba, VOC, gas karbon dioksida, dan gas karbon monoksida. Sejumlah besar aliran udara dari luar disuplai ke dalam kabin dapat membantu pembatasan kadar gas dan VOC yang 
tidak dihilangkan dari sistem filtrasi. (Schuchardt S, 2019)

Sejak dulu, standar kualitas udara untuk kabin pesawat komersial telah memenuhi kriteria yang aman dan sehat sesuai petunjuk dan panduan yang sudah ada. Peraturan tersebut umumnya berisi mengenai potensi bahaya yang berhubungan dengan gas emisi dari sumber dalam kabin, api, dan perubahan cuaca. (JR, 2009)

Organofosfat atau Tricresyl phosphate (TCP) merupakan salah satu zat Volatile Organic Compound (VOC) yang ditemukan menjadi salah satu hazard dari kualitas udara dalam kabin pesawat. Penelitian lain juga telah menunjukkan ada beberapa zat berbahaya lainnya yang terkandung dalam udara kabin. (Solbu K, 2011)

\section{High Efficiency Particulate Air} (HEPA) filter dalam penggunaannya telah dimanfaatkan secara luas dalam dunia kerja dan penerbangan untuk menjaga kualitas udara dalam ruangan. Prinsipnya seperti menyaring partijkel zat yang lebih kecil. Karbon aktif dalam bentuk charcoal telah diketahui secara luas dalam efeknya untuk menyaring sejumlah besar zat toksik seperti VOC dan bau tidak sedap dalam gedung dan kabin. Penelitian ini akan dibahas lebih mendalam mengenai efektifitas dari penggunaan HEPA filter dengan tambahan charcoal untuk meningkatkan Jurnal Kedokteran Vol. 06 No. 01 Desember 2020 efisiensi penyaringan dari VOC sehingga dapat memberikan dampak yang lebih baik terhadap kualitas udara kabin dalam pesawat. (Zhi Y, 2020)

\section{PEMBAHASAN}

\section{Kualitas Udara Kabin}

Kualitas udara kabin merupakan hal yang penting karena dampak kesehatan yang dapat terjadi pada manusia apabila kualitas udara tidak dijaga. Penyebaran bakteri ataupun virus lewat udara merupakan salah satu yang dapat mengancam kesehatan manusia saat ini, terutama dengan penyebaran penyakit infeksi seperti influenza yang dapat menyebar lewat udara. (Solbu K, 2011)

Zat-zat berbahaya lain seperti organofosfat dapat membahayakan kesehatan manusia. Salah satunya yang sering kita dengar dengan istilah aerotoxic syndrome yang dapat menyerang semua orang yang berpergian dalam pesawat terutama para pilot dan awak kabin yang cukup sering menghabiskan waktunya di dalam pesawat. Zat berbahaya tersebut umumnya dapat tersebar dari proses kimia yang terjadi dalam mekanisme kerja pesawat dan sulit untuk dihindari karena dihasilkan selama proses penggunaan pesawat berjalan. Dosis kecil tidak menutup kemungkinan dampak yang dapat dialami manusia 
dapat cukup signifikan di masa mendatang. (Solbu K, 2011)

Pesawat jet modern memiliki Environment Control System (ECS) yang mengatur aliran udara dalam kabin. Udara dari luar masuk ke dalam mesin dan dikompresi pada bagian depan pesawat yang terletak di depan bagian pembakaran sehingga tidak ada produk pembakaran yang masuk ke dalam kabin. Udara yang terkompresi digunakan untuk memberikan tekanan pada lingkungan kabin. Sistem ECS kemudian mengatur sirkulasi tersebut melalui HEPA Filter, sedangkan sisa udaranya yang lain diarahkan ke katup keluar pesawat. Kontaminan dapat masuk ke dalam kabin melalui sistem suplai udara. Zat yang digunakan untuk maintenance pesawat termasuk oli mesin pesawat, cairan hidraulik, zat pembersih, dan cairain deicing dapat mengkontaminasi ECS. Mekanisme aliran udara kabin adalah sebagai berikut: (Magoha, 2012)

1. Udara yang masuk ke bagian mesin jet akan terjadi peningkatan suhu yang sangat tinggi saat diberikan tekanan

2. Udara yang terkompresi akan melalui sistem pendinginan.

3. Udara dari luar akan masuk ke bagian pencampuran dimana akan diatur dengan perbandingan 50:50 bersama udara kabin yang

Jurnal Kedokteran

Vol. 06 No. 01 Desember 2020 diresirkulasi ulang yang sudah difilter oleh HEPA.

4. Udara dari bagian pencampuran disuplai ke dalam kabin secara berkelanjutan melalui outlet yang ada di atas kepala.

5. Udara akan keluar masuk kabin dengan jumlah yang sama setiap 2-3 menit.

Pada sebagian besar pesawat, sekitar 20 CFM dari campuran udara fresh dan udara resirkulasi disuplai untuk setiap penumpang. Hal ini memberikan pertukaran udara setiap beberapa menit sekali, atau sekitar 20-30 kali pertukaran udara setiap jam. Rasio perbandingan udara baru dan yang teresirkulasi adalah 50 : 50. Perbandingan ini disesuaikan dengan desain dengan kisaran 10-50\% dari total udara (Schuchardt S, 2019). Kualitas air kabin yang dimaksud disini adalah ukuran dari kadar zat polutan dalan udara. Faktor yang mempengaruhi kualitas udara kabin adalah : (JR, 2009).

1. Aliran udara

2. Perubahan udara

3. Ozon

4. Aerosol Mikroba

5. Aktivitas / tingkatan pernapasan

6. Volatile organic compounds (VOCs)

7. Karbondioksida

Sedangkan faktor lainnya yang dapat mempengaruhi kualitas udara kabin adalah : (JR, 2009) 
1. Fluorohydrocarbons

2. Karbonmonoksida (CO dari gas sisa mesin jet)

3. Suhu

4. Kelembaban

5. Penguapan dari material interior dan zat pembersih

6. Bioeffluents

7. Produk higiene pribadi

8. Alergen

9. Agen infeksi atau inflamasi

10. Alkohol

11. Formaldehid

12. Cairan de-icing

13. Debu dan partikel material lain

14. Dry ice untuk menjaga makanan tetap dingin

15. Cairan toilet

16. Cairan penolak serangga

17. Peptisida Piretiroid

Banyak sekali hal yang dapat menganggu kualitas udara kabin. Sehingga apa yang akan dipelajari maka dalam tulisan ini hanya akan dibahas mengenai khusus VOC dimana zat ini merupakan salah satu dari zat berbahaya yang dapat mengganggu kualitas kabin udara. (JR, 2009)

\section{Zat Berbahaya}

Sejumlah zat berbahaya yang ditemukan dapat menyebabkan gangguan kesehatan misalnya seperti organophosphates, tributyl phosphate (TBP), triphenyl phosphate (TPP), Jurnal Kedokteran Vol. 06 No. 01 Desember 2020 aldehydes (Contoh : formaldehyde, acetaldehyde, hexanal), dan berbagai macam VOC / Volatile Organic Compound (aromates, aliphatic hydrocarbons, organic acids, alcohols, terpenes, cyclic siloxanes, esters, ketones, glycols). (Schuchardt S, 2019) (Zhi Y, 2020)

Dalam suatu penelitian ditemukan bahwa kadar zat tersebut umumnya tidak berada dalam kadar berbahaya (dosis yang ditemukan rata-rata sama dengan dosis pada perkantoran umumnya). Apabila dosis yang diterima tersebut terus menerus dialami maka tidak menutup kemungkinan dapat menyebabkan gejala pada kesehatan. (Zhi Y, 2020)

Aerotoxic syndrome merupakan sekumpulan gejala yang terdiri atas rasa mual, pusing, sakit kepala, muntahmuntah, bahkan beberapa kasus hingga terjadi pingsan. Sindroma ini sering dialami oleh awak kabin dalam pesawat. Penyebab dari gejala ini masih dicari tahu lebih namun ada teori yang menyebutkan dimana zat organofosfat yang dihasilkan oleh minyak dari mesin pesawat menjadi penyebab dari sindroma ini meskipun ada penelitian yang membuktikan sebaliknya. (Zhi Y, 2020)

Sindroma aerotoksik merupakan sebuah frasa yang digunakan oleh Chris Winder dan Jean Christope Balouet pada tahun 2000 untuk menggambarkan klaim 
mereka terhadap dampak jangka pendek dan panjang terhadap kesehatan akibat bernafas di udara kabin pesawat yang diduga terkontaminasi zat toksik dari oli mesin dan zat kimia lain. (Zhi Y, 2020) Mesin jet umumnya memerlukan oli sintetik untuk lubrikasi. Oli tersebut seperti TCP, sebuah organofosfat, yang dapat berdampak toksik bagi manusia. Umumnya mesin memiliki sebuah seal untuk mencegah kebocoran oli masuk ke dalam aliran udara kabin. Kondisi seal tersebut rusak maka dapat terjadi kebocoran oli ke dalam kabin. Umumnya hal ini dapat dideteksi dengan adanya bau seperti wajan terbakar, atau yang lebih serius adanya asap dalam kabin. Istilah dalam penerbangan hal ini yang disebut sebagai fume event. (Zhi Y, 2020)

Organofosfat merupakan istilah umum untuk ester dari asam fosforik karena zat yang mirip seperti organofosfat merupakan zat yang mengandung ikatan fosforil dan tiofosforil yang merupakan ester, amid, atau derivat thiolic dari fosforik, fosfonik, atau asam fosfinik dengan perbedaan komposisi dari oksigen yang terikat, karbon, nitrogen, atau atom sulfur dan diklasifikasikan menjadi 14 tipe. Sebagian besar dari zat tersebut digunakan dalam peptisida, gas syaraf, zat anti api, dan parasitisida. Contoh tabun dan sarin merupakan zat yang

Jurnal Kedokteran

Vol. 06 No. 01 Desember 2020 dikenal luas yang berasal dari proses penyempurnaan peptisida. (Solbu, 2011)

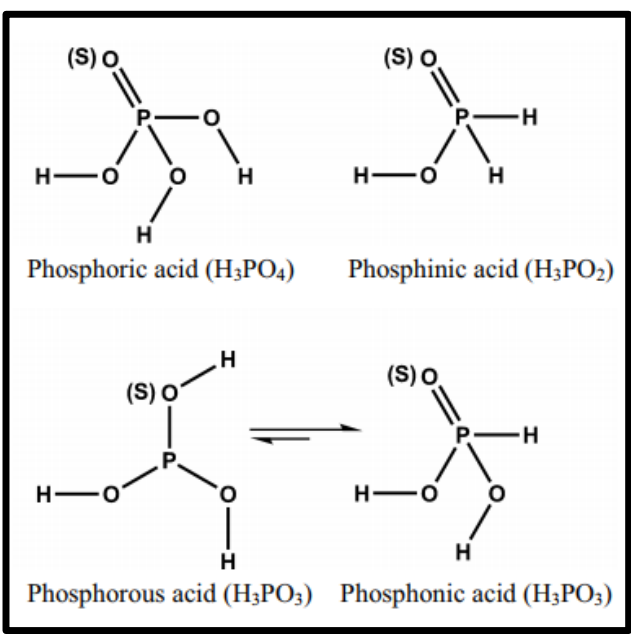

Gambar 1. Bentuk rantai zat organofosfat

Organofosfat yang disebutkan sebagai ester dari asam fosforik dikenal dalam penggunaannya di dalam industri seperti penghambat api, zat aditif dalam insektisida, dan sebagai aditif pengontrol tekanan dalam oli hidraulik serta lubrikan. Zat aditif ini digunakan dalam oli turbin untuk meningkatkan lubrikasi dan memiliki properti anti korosif. Berbagai jenis oli lainnya yang mengandung isomer TCPdan juga triaril atau trialkil. Oli turbin jet umumnya mengandung konsentrasi organofosfat yang lebih tinggi dengan rerata kandungan TCP di angka satu sampai lima persen. (Solbu, 2011)

Tipe organofosfat yang umum digunakan dalam oli hidraulik dan turbin pada industri aviasi, beberapa jenisnya yang dapat ditemukan adalah p-ISSN 2460-9749 e-ISSN 2620-5890 
butylphosphates triisobutyl phosphate (TiBP), tri-n-butyl phosphate (TnBP), dan dibutylphenyl phosphate (DBPP) dan umumnya sering digunakan dalam oli hidraulik untuk pesawat jet. (Solbu, 2011)

\section{Dampak Organofosfat dalam}

\section{Kesehatan}

Dampak organofosfat terhadap kesehatan manusia masih belum diteliti lebih lanjut. Ada yang menyebutkan bahwa zat organofosfat berperan dalam sindroma aerotoksik namun tidak ada penelitian yang menyebutkan adanya hubungan antara paparan zat tersebut dengan kejadian paralisis pada manusia. Penelitian yang lainnya menemukan bahwa pada tahun 1930 terjadi paparan TCP pada minuman sehingga menyebabkan kejadian epidemik paralisis, terutama pada kaki. Selain itu seorang mekanis dari Skandinavia yang terpapar oli hidraulik selama beberapa tahun ditemukan mengalami paralisis.

Zat organofosfat menyebabkan gangguan konduktivitas syaraf dalam menghantarkan impuls sehingga menyebabkan terjadinya paralisis. (Solbu, 2011)

Keracunan akut pada organofosfat dapat muncul dalam waktu beberapa menit hingga jam setelah zat terminum, dimana terjadi inhibisi ireversibel dari enzim acetylcholinesterase (AChE) yang Jurnal Kedokteran Vol. 06 No. 01 Desember 2020 menyebabkan akumulasi asetilkolin pada sinaps dari syaraf dan diikuti peningkatan aktivitas syaraf yang persisten. Selain dampak akut, organofosfat dapat menyebabkan sindroma lain seperti sindroma intermediat, neuropati / polineuropati tertunda, serta gejala neuropsikiatrik kronis. (Solbu, 2011) Sindroma intermediat umumnya muncul 24 sampai 96 jam setelah fase akut dan menyebabkan gangguan pada otot pernapasan, ekstremitas proksimal, leher, dan otot yang dipersarafi saraf kranial. Sindroma neuropati tertunda akan muncul pada dua sampai tiga minggu setelah paparan akut dimana akan terjadi mati rasa dan kelemahan pada kaki yang progresif ke bagian atas. Sindroma neuropati diperkirakan muncul akibat inhibisi dari neuron protein neuropathy target esterase (NTE). Penelitian juga menemukan bahwa ada hubungan kuat antara paparan organofosfat dengan perkembangan gangguan neuropsikiatri akibat paparan kronis dalam kadar rendah. (Solbu, 2011)

Isomer dari TCP yaitu tri-o-cresyl phosphate (ToCP) juga ditemukan berdampak terhadap sistem saraf. Meta dan para isomer dalam bentuk tri- $m$ cresyl phosphate (TmCP) dan tri- $p$-cresyl phosphate (TpCP) juga memiliki dampak kesehatan dimana isomer mono-ortho TCP diidentifikasi sebagai yang paling toksik terhadap neuropati. Triphenyl 
phosphate (TPP) merupakan inhibitor yang poten terhadap aktivitas enzim karboksilesterase sel monosit dan menyebabkan dermatitis kontak alergi serta efek hemolitik. Tri-n-butyl phosphate (TnBP) telah ditemukan memiliki efek sitotoksik dan dapat menyebabkan tumor. (Solbu, 2011)

\section{Paparan Organofosfat}

Oli hidraulik dan turbin sering digunakan dalam sistem mesin dengan tekanan dan suhu tinggi. Tujuannya adalah meningkatkan resiko potensi penyebaran uap, gas, atau cipratan oli. Paparan terhadap organofosfat dari oli turbin dan hidraulik lewat penguapan dan aerosol dapat terjadi saat bekerja. Pekerjaan teknisi dapat meliputi penggantian oli, perbaikan, maintenance dari sistem hidraulik serta mesin yang terpresurisasi. (Solbu, 2011)

Petugas pengangkut barang juga saat memasukkan atau mengeluarkan barang posisinya dekat dengan pesawat dan pipa panas dari mesin, sehingga dapat menyebarkan paparan dari oli turbin secara penguapan atau aerosol, serta kemungkinan adanya kebocoran pada sistem hidraulik. Awak kabin dapat terpapar oleh oli turbin karena udara dalam kabin diatur dalam aliran tertutup melalui inti mesin. Zat organofosfat dalam kabin yang menjadi kontaminan

Jurnal Kedokteran

Vol. 06 No. 01 Desember 2020 utama pada saat kejadian adanya asap dalam kabin. (Solbu, 2011)

Tindakan pencegahan diperlukan untuk mengurangi resiko paparan zat organofosfat dalam kabin. Salah satu caranya yang hingga kini sering digunakan adalah dengan menggunakan HEPA Filter yang diklaim dapat menyaring partikel udara hingga $99 \%$. Melalui penelitian terbaru, filter HEPA ini ditambahkan dengan bahan karbon aktif untuk meningkatkan efektifitasnya. (Solbu, 2011)

\section{Sejarah Penggunaan HEPA Filter}

Ide pembuatan HEPA terlahir saat masker gas yang digunakan oleh tentara yang berperang saat perang dunia kedua. Selembar kertas yang dimasukkan dalam masker gas memiliki efektifitas tinggi terhadap penyaringan gas kimia. Tentara Inggris kemudian menirukan cara ini. Masker perorangan tidak praktis maka dibuatlah desain gabungan blower mekanik dan air purifier, yang mengandung kertas selulosa-asbestos di dalamnya. Desain gabungan inilah yang menjadi cikal bakal pembuatan filter HEPA. (AF., 2019)

Fase selanjutnya filter HEPA didesain tahun 1940 an dan digunakan pertama kali dalam proyek Manhattan untuk mencegah penyebaran kontaminan radioaktif di udara. Tentara Amerika kemudian membuat suatu desain untuk 
menyaring material radioaktif dari udara. Seorang peneliti bernama Irving Langmuir merekomendasikan suatu filter yang dapat menyaring ukuran partikel hingga 0.3 mikron. (AF., 2019)

Pada tahun 1950 HEPA Filter diperkenalkan dan menjadi nama paten dari produk HEPA yang pertama. Filter tersebut telah berevolusi untuk menjadi lebih baik karena tuntutan kebutuhan kualitas udara yang tinggi di dalam industri teknologi seperti penerbangan, farmasi, rumah sakit, layanan kesehatan lain, bahan bakar nuklir, tenaga nuklir, dan pabrik sirkuit terintegrasi. (AF., 2019)

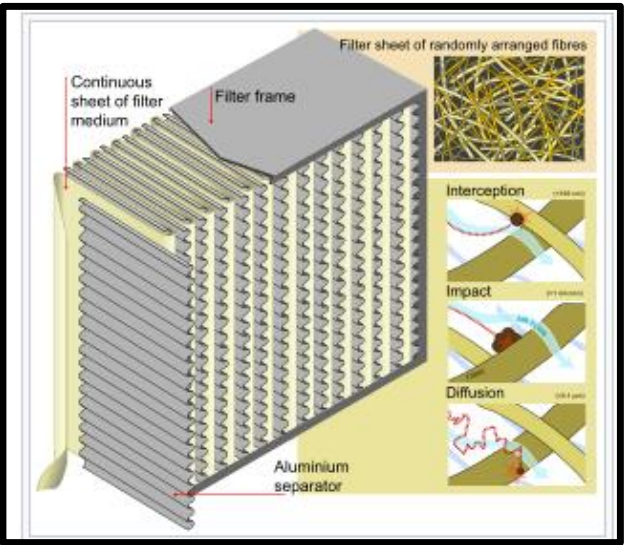

Gambar 2. Desain HEPA Filter

\section{Cara Kerja HEPA Filter}

Filter terbuat dari sejumlah gabungan serat fiber teratur yang dicampur secara acak. Serat fiber tersebut umumnya terdiri atas fiberglass yang memiliki diameter 0.5 - 2 mikrometer. Poin penting yang bermanfaat bagi fungsi filter ini adalah diameter serat Jurnal Kedokteran

Vol. 06 No. 01 Desember 2020 fiber, ketebalan fiber, dan velositas permukaan. Ruang kosong antar serat fiber dalam HEPA umumnya lebih besar dari 0.3 mikron. HEPA filter dirancang untuk menyaring partikel polutan yang lebih kecil. Partikel tersebut akan terjebak (menempel pada fiber) melalui kombinasi dari 3 mekanisme : (NN, n.d.)

1. Difusi

Mekanisme penguat yang dihasilkan oleh tumbukan molekul gas dari partikel terkecil, terutama dibawah 0.1 mikro dalam diameter, dimana akan terhambat dalam jalurnya melalui filter. Sesuai dengan hukum Brownian motion dan meningkatkan probabilitas dimana partikel akan terhenti oleh interception atau impaction. Mekanisme ini menjadi dominan pada aliran udara yang rendah.

\section{Interception}

Partikel yang mengikuti jalur lurus dalam aliran udara dalam satu radius sebuah serat fiber akan menempel pada fiber tersebut.

\section{Impaction}

Partikel yang lebih besar tidak dapat menghindari serat fiber dalam mengikuti bentuknya yang melengkung dari aliran udara. Tujuannya adalah membuat partikel tersebut akan terjebak dan terikat pada salah satu serat. Efek 
dari impaction akan meningkat seiiring penurunan pemisahan fiber dan aliran udara yang memiliki velocity yang tinggi.

Proses difusi umumnya akan menyaring partikel berukuran dibawah 0.1 mikron sedangkan impaction dan interception akan menyaring partikel diatas 0.4 mikron. Di antaranya, mendekati titik Most Penetrating Particle Size (MPPS) 0.21 mikron, baik difusi maupun intersepsi tidak efektif. Kelemahan fungsi filter dengan spesifikasi HEPA adalah retensi dari partikel hingga ukuran 0.3 mikron. Hal sebaliknya dapat terjadi untuk partikel berukuran lebih kecil dari MPPS. Hal ini dikarenakan partikel tersebut dapat berperan sebagai lokasi nukleasi untuk sebagian besar kondensasi dan membentuk partikel dekat MPPS.

(Devine S, 2013)

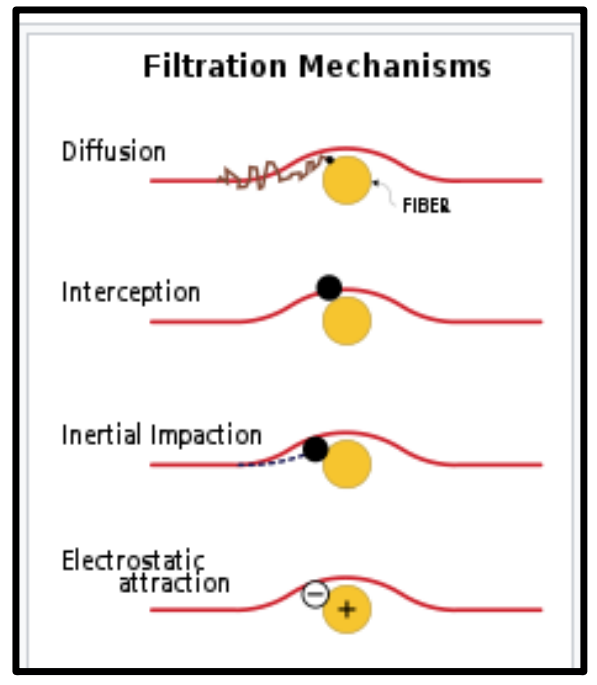

Gambar 3. Mekanisme kerja HEPA Filter

Jurnal Kedokteran

Vol. 06 No. 01 Desember 2020
HEPA Filter didesain untuk menangkap partikel yang sangat kecil secara efektif namun mereka tidak dapat menyaring gas dan molekul bau. Beberapa keadaan seperti VOC (Volatile Organic Compound), penguapan zat kimia, asap rokok, bau binatang, atau gas dari kentut manusia menggunakan bantuan karbon teraktivasi (Charcoal) untuk menyaringnya. Filter dengan lembaran karbon diklaim memiliki tingkat efektifitas yang lebih tinggi dibanding yang menggunakan serbuk karbon. Teknologi terbaru ini dinamakan High Efficiency Gas Adsorption (HEGA) dan dipakai pada awalnya sebagai perlindungan tentara Inggris dari perang kimia. (Devine S, 2013)

\section{Karbon Aktif}

Karbon aktif disini merupakan suatu bentuk karbon yang diproses agar memiliki ukuran dan volume pori-pori yang kecil untuk meningkatkan luas permukaan area untuk meningkatkan adsorpsi dan reaksi kimia. Kemampuan mikropori yang tinggi yaitu satu gram karbon aktif memiliki luas area permukaan lebih dari $3000 \mathrm{~m} 2$ dan semakin tinggi luas permukaan maka tingkat aktivasi adsorpsi yang meningkat. Karbon aktif cukup banyak digunakan 
dalam berbagai bidang misalnya : (Wikipedia, 2020)

1. Aplikasi industri

Aplikasi ini digunakan dalam proses finishing bahan metal untuk purifikasi dari solusi electroplating.

Contoh dalam purifikasi bahan organik dari nikel.

2. Medis

Karbon aktif digunakan dalam keracunan, diare, overdosis bahan oral, gangguan kentut. Karbon aktif kurang efektif untuk mengatasi keracunan akibat asam / basa kuat, sianida, besi, litium, arsenik, metanol, etanol, atau glikol etilen. Penggunaan yang salah dapat menyebabkan aspirasi pneumonia.

3. Analisis kimia

Penggunaannya bersama celite, dapat digunakan dalam proses pemisahan kromatografik dari karbohidrat dengan solusi etanol. Tujuan lainnya dapat digunakan untuk ekstraksi antikoagulan oral seperti dabigatran, apixaban, dan edoxaban dari sampel plasma darah.

4. Aplikasi Lingkungan

Digunakan untuk menghilangkan polutan dari udara atau air di lingkungan misalnya :
a. Pembersihan limbah
b. Remediasi air tanah
c. Filtrasi air minum
d. Purifikasi udara

Jurnal Kedokteran

Vol. 06 No. 01 Desember 2020 e. Menangkap VOC dari cat

5. Agrikultur

Teknik ini digunakan dalam pertanian untuk produksi ternak dan pembuatan anggur. Penggunaan lainnya adalah dalam peternakan sebagai peptisida, aditif pakan ternak, dan bahan disinfektan.

6. Purifikasi distilasi akohol

Teknik ini digunakan untuk filtrasi vodka, whiski dari bahan organik lain yang dapat mempengaruhi rasa, bau, dan warna.

7. Penyimpanan bahan bakar Teknik ini digunakan dalam penyimpanan gas hidrogen lewat hukum Van der Waals agar tidak ada kebocoran saat terkena suhu panas. Penyimpanan dengan metode ini memiliki keuntungan dalam menghemat ukuran tempat penyimpanan. Penghematan ini terjadi karena dapat disimpan dalam tekanan rendah, massa rendah, dan volume rendah.

8. Filtrasi udara

Teknik ini digunakan dalam udara terkompresi untuk menghilangkan uap dari oli, bau, dan hidrokarbon. Karbon aktif juga dapat digunakan untuk menyaring gas radioaktif dari reaktor turbin nuklir.

9. Purifikasi kimia

Teknik ini digunakan untuk menyaring solusi dari molekul 
organik mengandung warna yang tidak diinginkan.

10. Membersihkan zat merkuri Karbon aktif yang digabung dengan sulfur atau iodin dapat digunakan untuk menyaring emisi merkuri dari pembakaran batu bara.

Karbon aktif cukup banyak digunakan dalam berbagai bidang lainnya. Beberapa jenis Charcoal yang kita ketahui : (Wikipedia, 2020)

1. Karbon aktif dalam bentuk bubuk. Karbon aktif dibuat dari bentuk partikulat sebagai bubuk atau granul halus berukuran kurang dari $0.1 \mathrm{~mm}$ dengan diameter $0.15-0.25 \mathrm{~mm}$. Rasio luas permukaan terhadap volume yang dicapai cukup tinggi dengan jarak difusi yang kecil. Material bubuk merupakan bahan yang baik. Bahan karbon aktif ini diperoleh dengan penggerusan partikel karbon.

2. Karbon aktif bentuk granular Bentuk granuler memiliki ukuran partikel yang lebih besar dibanding bentuk bubuk sehingga memiliki permukaan eksternal yang lebih kecil. Bentuk granular ini cocok untuk adsorpsi gas dan uap karena mereka bedifusi dengan cepat, contohnya instalasi pengolahan air, penghilangan bau, dan pemisahan komponen dalam suatu sistem aliran zat.

Jurnal Kedokteran

Vol. 06 No. 01 Desember 2020
3. Karbon aktif bentuk extruded

Bentuk ini mengkombinasi bentuk bubuk dengan pengikat yang digabungkan bersama dan diubah menjadi bentuk silinder dengan diameter $0.8-130 \mathrm{~mm}$. Bentuk ini banyak digunakan untuk aplikasi fase gas karena rendahnya penurunan tekanan dan kekuatan mekanis yang tinggi.

4. Karbon aktif bentuk bead

Bentuk ini dibuat dari petroleum dan memiliki ukuran diameter 0.35 $0.80 \mathrm{~mm}$. Mirip bentuk yang dapat diubah dan bentuk ini memiliki keuntungan karena rendahnya penurunan tekanan dan kekuatan mekanis yang tinggi. Hal ini berbeda dengan ukuran yang lebih kecil. Bentuk bead ini juga bermanfaat untuk jenis cair misalnya dalam penyaringan air.

5. Karbon aktif bentuk impregnated Karbon berpori mengandung berbagai jenis bahan inorganik seperti iodin, perak, kation (Al, Mn, $\mathrm{Zn}, \mathrm{Fe}, \mathrm{Li}, \mathrm{Ca}$ ) yang dibuat khusus untuk aplikasi kontrol polusi udara dalam museum. Kemampuan antimikroba dan antiseptik membuat bentuk ini digunakan untuk mempurifikasi air minum.

6. Karbon aktif dengan lapisan polimer Karbon yang berpori akan dilapisi dengan polimer untuk memberi 
pelindung tetapi tanpa memblokir porinya karena permeabilitas. Bahan ini berguna untuk perpindahan zat dimana darah dari sampel melalui bahan adsorben untuk menghilangkan zat toksik.

7. Karbon aktif bentuk woven Teknologi yang memproses serat karbon menjadi kain. Kemampuan menyaringnya yang sangat tinggi mencapai 500 - $1500 \mathrm{~m} 2 / \mathrm{g}$. Bentuk ini digunakan untuk superkapasitor, penyerap bau, dan industri pertahanan terhadap kimia-biologiradiasi-nuklir.

\section{Metode Penyaringan Udara dengan \\ HEPA dan Charcoal}

Penggunaan HEPA Filter dengan bahan aditif karbon aktif telah dijelaskan dalam banyak penelitian. Metode ini digunakan dalam International Space Station (ISS) dalam pemanfaatannya. Karbon aktif dalam hal ini Charcoal memiliki fungsi sebagai material untuk menyaring VOC. (Zhi Y, 2020)

Mekanisme kerja karbon aktif pada HEPA filter mirip dengan filter pada umumnya hanya saja dengan penambahan karbon aktif maka proses adsorpsi zat VOC akan lebih efektif dikarenakan adanya karbon dalam bentuk bubuk atau granul yang meningkatkan luas permukaan penyerapan zat. Sistem kerja HEPA filter yang menggunakan Jurnal Kedokteran Vol. 06 No. 01 Desember 2020 proses perpindahan zat, impaction, dan interception maka penggunaan charcoal akan membantu proses penyerapan zat atau adsorpsi sehingga lebih baik dalam menurunkan kadar zat VOC yang bocor ke dalam kabin. (Zhi Y, 2020)

Mekanisme umum dalam penyaringan VOC dengan filter kimia adalah adsorpsi fisik yang berhubungan dengan hukum van der Waals. Hukum ini menyebutkan adanya gaya tarik-menarik dari atom, molekul dan permukaan. Penggunaan hukum ini adalah pada proses penempelan kaki binatang di tembok. Bentuk mikrostruktur dapat mempengaruhi hukum van der Waals sehingga dapat mempengaruhi kemampuan adsorpsi dari filter kimia. (Zhi Y, 2020)

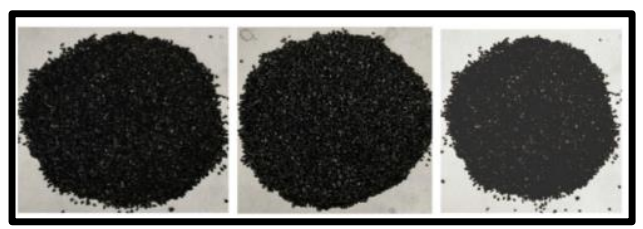

Gambar 4. Jenis karbon aktif yang digunakan dalam kabin pesawat

Penelitian dari Soibu et al mengemukan suatu metode untuk mengukur kadar organofosfat dalam kabin pesawat. Peneliti menemukan bahwa pemasangan HEPA filter menjadi lokasi dimana penyaringan VOC terukur signifikan. Penelitiannya juga menggunakan metode pengelapan 
dengan kain karbon dimana ditemukan bahwa kadar TCP juga cukup signifikan. (Solbu K, 2011)

Rosenberger et al meneliti mengenai efektifitas penggunaan HEPA filter dengan charcoal dalam menjaga kualitas udara kabin. Rosenberger et al juga menemukan bahwa terdapat penurunan kadar VOC sebesar $30 \%$ dengan penambahan karbon aktif dibanding dengan HEPA Filter biasa. Peningkatan kadar VOC paling tinggi terjadi pada saat pesawat melakukan $d e$ icing. (Rosenberger, 2018)

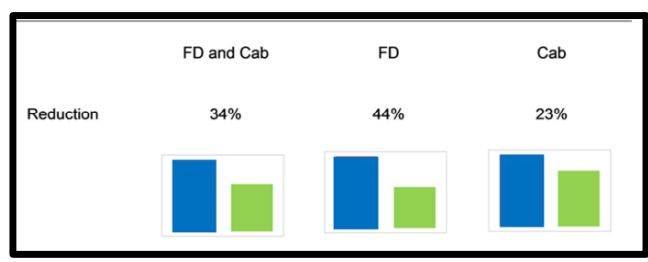

Gambar 5. Hasil Penelitian Rosenberger et al dimana terjadi penurunan kadar organofosfat dalam kabin dan kokpit setelah dipasang charcoal (hijau) dibandingkan hanya filter HEPA biasa (biru)

Rosenberger juga mengemukakan bahwa HEPA filter dengan bahan tambahan karbon aktif membantu mengurangi bau tidak sedap sehingga diperkirakan dapat meningkatkan kenyamanan bagi penumpang pesawat. Jurnal Kedokteran Vol. 06 No. 01 Desember 2020
Peneliti juga menemukan bahwa keluhan bau tidak enak yang sering dikeluhkan penumpang saat naik pesawat ternyata tidak berhubungan dengan peningkatan kadar VOC (Rosenberger, 2018). Penelitian dari Schuchardt et al menemukan bahwa pada penerbangan dengan pesawat Boeing B787 ditemukan kadar konsentrasi VOC atau aldehid yang lebih rendah dibanding pesawat jenis lain. Pesawat ini menggunakan HEPA filter yang dikombinasi dengan karbon aktif. Pesawat Airbus A321 juga ditemukan memiliki kadar VOC yang lebih rendah karena alasan yang sama. (Schuchardt S, 2019)

Zhi et al juga menemukan bahwa penggunaan karbon aktif dalam HEPA filter di pesawat. Kesimpulannya didapatkan bahwa adanya efisiensi penggunaan tenaga dan penyaringan yang lebih efektif 3.2 kali lebih baik untuk zat toluen sebesar $369.1 \mathrm{mg}$ per 1 $\mathrm{kJ}$ dibanding filter biasa yang digunakan industri lain. Zhi et al juga menemukan dalam simulasi bahwa penggunaan karbon aktif meningkatkan koefisien penyaringan sebesar $53 \%$ dibanding filter mikroelektronik industri karena filter dalam pesawat memiliki volume pori yang lebih besar. (Zhi Y, 2020)

\section{PENUTUP}

Semakin pentingnya kesehatan dan kenyamanan bagi penumpang 
pesawat, maka kemajuan teknologi haruslah dimanfaatkan dengan semaksimal mungkin. Kualitas udara kabin menjadi poin yang sangat diperhatikan dalam dunia penerbangan. Masalah kualitas udara dalam kabin pesawat memiliki dampak kesehatan yang dapat terjadi apabila kualitasnya tidak dijaga dengan baik, terutama dengan adanya isu penyebaran mikroba dan zat partikulat berukuran kecil dalam pesawat. (JR, 2009)

Penentu kualitas udara kabin adalah tingkat konsentrasi zat VOC dihasilkan dari kebocoran oli mesin pesawat yang menguap akibat panas dari mesin dan masuk ke dalam sistem sirkulasi udara kabin. Berbagai metode telah ditemukan untuk mengukur kadar zat VOC dengan tujuan untuk pencegahan dampak kesehatan yang dapat terjadi. Literatur dan sumber yang ada sekarang ini menunjukkan bahwa penggunaan HEPA filter sangat membantu dalam hal meningkatkan kualitas udara dalam kabin pesawat. Filter ini dapat menyaring zat-zat berbahaya seperti VOC, membantu mengurangi bau tidak sedap, menyaring gas karbonmonoksida, partikel debu, mikroorganisme (bakteri dan virus) dan zat kimia lainnya. Penggunaan HEPA filter tentu saja menjadi poin penting dalam menjaga higienitas dan kebersihan udara. Jenis filter ini banyak digunakan Jurnal Kedokteran Vol. 06 No. 01 Desember 2020 dalam berbagai industri bahkan dalam penggunaan perumahan pribadi yang terpasang dalam air conditioner. (JR, 2009)

Penggunaan karbon aktif dalam HEPA filter memberikan keuntungan tambahan. Keuntungan ini adalah dapat membantu meningkatkan efisiensi penyaringan filter yang sudah ada sehingga akan lebih meningkatkan higienitas dalam kualitas udara kabin. Peneliti merekomendasikan penggunaan charcoal dalam industri penerbangan untuk meningkatkan pencegahan penyebaran zat kimia dan biologi serta partikel debu yang dapat menyebabkan gangguan kesehatan pada penumpang pesawat komersial. (Zhi Y, 2020)

\section{DAFTAR PUSTAKA}

AF., I., 2019. The History of HEPA Filters. [Online]

Available at:

https://www.apcfilters.com/thehistory-of-hepa-filters/ [Diakses 8 May 2020].

Devine S, O. S. S. A. T. D., 2013. A Science-Based Approach to Selecting Air Filters.

JR, D., 2009. Fundamentals of aerospace medicine.. 4th penyunt. Philadelphia: Lippincott Williams \& Wilkins.

Magoha, P. W., 2012. Incident-response monitoring technologies for aircraft cabin air quality. Kansas: Kansas State University.

NN, t.thn. Mechanisms of Filtration for High Efficiency Fibrous Filters (Application Note ITI-041), s.1.: s.n.

Rosenberger, W., 2018. Effect of charcoal equipped HEPA filters on cabin air quality in aircraft. Build Environ., pp. 358-365. Schuchardt 
S, K. W. R. W., 2019. abin air quality - Quantitative comparison of volatile air contaminants at different flight phases during 177 commercial flights. Build Environ, pp. 498-507.

Solbu, H. D. R. O. S. T. D. E. T. L. B. B. E. L. P. M., 2011.

Organophosphates in aircraft cabin air and cockpit air - method development and measurements of contaminants. J. Environ. Monit., pp. 1393-1403.
Wikipedia, 2020. Activated Carbon.

[Online]

Available at:

https://en.wikipedia.org/wiki/Activa ted carbon [Diakses 8 May 2020].

Zhi Y, L. J., 2020. Analysis of chemical filter performance and activated carbon microstructure at low concentration. Build Environ, p. 106563 